\title{
Algorithmic work coordination and workers' voice in the COVID-19 pandemic \\ The case of Foodora/Lieferando
}

Jasmin Schreyer

Jasmin Schreyer is a Research Associate in the Department of Sociology at the University of Erlangen-Nuremberg, Germany.

\begin{abstract}
The COVID-19 pandemic exacerbates the conflictual nature of work in the digital platform economy as if it were ignited under a magnifying glass. In this context, this article focuses on the logic of control of algorithmic labour coordination, adopting a qualitative case study approach. In a situation in which the technical infrastructure of online platforms generally impedes labour protests, it examines the case of Lieferando (formerly Foodora) in Germany, where, unusually, the on-demand workforce is employed. It concludes that in this situation, the algorithmic management of Lieferando facilitates labour protests because of a lack of communication between employer and worker. Furthermore, in the COVID-19 pandemic, institutionalised relationships function as a countervailing power to that of the employer, forcing it to act.
\end{abstract}

\section{KEY WORDS}

Platform Economy, On-demand Workforce, Algorithmic Management, Algorithmic Work Coordination, Workers' voice, Co-determination, COVID-19 Pandemic

\section{Introduction}

The digital platform economy, in particular platform-based delivery services, has been a beneficiary of the COVID-19 pandemic. The increasing importance of platforms is associated with ambivalent effects on the world of work and of daily life. The platform economy has experienced rapid growth and encompasses a wide array of digitally 
mediated transactions. The technical infrastructure of platforms, with its ability to facilitate transactions among many producers at low cost, which is extremely scalable, has given rise to a 'gig economy' with an on-demand workforce (De Stefano, 2016; Kuhn \& Galloway, 2019; Healy, Pekarek \& Vromen, 2020). It promises employment relationships that are flexible in terms of time and place, and an increased degree of personal responsibility of individual workers. This new workforce relies on web-based communication through digital platforms for the coordination of its work (Huws, 2014; 2016).

A crucial characteristic of digital labour platforms is their reliance on algorithms that perform management functions. On the one hand, the digital infrastructure of platforms can be designated as 'algorithmic management' (Rosenblat \& Stark, 2016), a term that describes the implemented and automated mechanisms through which the digital workforce is directed in terms of work coordination and behaviour. On the other hand, the working conditions of on-demand workers are both precarious and exploitative, and their performance is permanently under surveillance as a result of this algorithmic management (van Doorn, 2017, 2020; Goods, Veen \& Barratt, 2019; Kellogg, Valentine \& Christin, 2020). Because the algorithm provides its workforce with modular units of work, no specific qualification is required. However, for the providers, this means being employed as a 'solo freelancer' or a contractor from job to job and having no job security at all (Healy, Nicholson \& Pekarek, 2017; Huws et al., 2017). So, against the often postulated atomisation of workers and its effects of de-solidarising (Wewer, 2016), it is not surprising that protests by platform workers are on the rise, especially in the industries of food delivery and courier work which show the highest number of labour protests (Joyce et al., 2020).

Taking these ambivalent considerations into account, in this article I examine an example from the food-delivery industry, part of the location-based gig economy, because it represents an accelerated trend toward precarious working conditions (Duggan et al., 2020). In my qualitative case study, I focused on the algorithmic infrastructure of the platform Foodora/Lieferando, which governs its employees through algorithmically-driven and standardised work coordination. As I show, this opens up multiple conflicts between the enterprise and its workers relating to working conditions, working relations, control and autonomy and co-determination. Especially in times of the COVID-19 pandemic, a (strong) works council as a countervailing power is essential for the employees to protect their health, needs and interests.

\section{Algorithmic work coordination evokes workers' voice}

Platforms as digital marketplaces establish business models in which operating companies no longer necessarily own their means of production because these are brought in by the users as participants. This corresponds with the type of platform designated as 'lean' (Srnicek, 2017), which acts as an intermediary coordinating the supply and demand of products among the participants, reducing the transaction costs of exchange and (supposedly) creating symmetry in information and social relations (Lehdonvirta, 2018). However, in practice, participants pay for the platform twice: with money as well as with their data. So, the algorithmic infrastructure of the platform is in reality a central control authority, which is why an asymmetry of power emanates from the platform when it acts as an intermediary (van Doorn, 2020), because only the 
platform can oversee, connect and aggregate the data streams from all participants (Slee, 2016; Frenken \& Schor, 2017; Dijck, Poell \& Waal, 2018; Duggan et al., 2020). This means that platform labour shows a marked asymmetry between the platformoperating company and the providers in favour of the platform.

While platforms advertise their work as self-determined, independent and flexible, with no need for special qualifications, workers have to bring their own working materials and work as contractors from job to job with no employment security at all (Healy et al., 2017; Schreyer \& Schrape, 2018; Marrone \& Finotto, 2019). Moreover, platforms often negate their responsibilities towards their workers by shifting risks onto them. This reflects the disparity between those who design and provide the algorithms and those who physically run the service. Because the algorithmic management coordinates the whole workflow through modular units, it functions as the key resource for managing the workforce, using tracking mechanisms that appear to be objective. Thereby the algorithms and their mode of operation remain opaque to the workforce (Levermann, 2018; Wood et al., 2019; Goods et al., 2019).

Moreover, the technical infrastructures of platforms use algorithms 'to direct workers by restricting and recommending, evaluate workers by recording and rating, and discipline workers by replacing and rewarding' (Kellogg et al., 2020: 368). On the one hand, these methods provide the employer with real-time and predictive analytics covering the whole work process and enable the company to measure and control its workforce quantitatively and normatively using rankings and gamification (Vallas \& Schor, 2020). On the other hand, the complex evaluations of participants' behaviour ensure the attractiveness of the service and generate a 'behavioural surplus' (Zuboff, 2018: 279). For this reason, the autonomy and agency of gig workers are experienced as limited (van Doorn, 2017; Kirchner \& Schüßler, 2019; Schreyer, 2020). So, platform workers, as service providers, are in a vulnerable position (van Doorn, 2017). There is a division between workers 'over the algorithm' (the people, who design or have the theoretical possibility of gaining insights into how it works) and those who work 'under the algorithm' (the workers who physically - provide the work), creating an information asymmetry whose effect is to prevent protest, exacerbated by the absence of a centralised workspace and social relationships and by the use of digital control mechanisms (Marrone \& Finotto, 2019). Furthermore, the algorithmic infrastructure generates 'dependence and determines the rules that shape, afford, and limit worker agency' (Duggan et al., 2020).

It is undoubtedly complicated to organise collective action in the context of platform labour. The fragmented nature of the work and the way that the traditional employment relationship is undermined makes this difficult, but not impossible, as examples from the ride-hailing or food-delivery services show (Tassinari \& Maccarrone, 2020).

In the case of cycle messengers working in food-delivery logistics, transnational, coordinated resistance on the part of riders to improve their working conditions and remuneration structures began to emerge in 2016. In Germany, some works councils have institutionalised and represented the rights of courier drivers since 2017. These developments show, that, in contrast to the frequent (over)emphasis on the control paradigm (Kirchner \& Schüssler, 2019) in the literature discussed above, the algorithmic management of the platform was unable to prevent the (trans)national and self-organised 
initiatives and associations of courier drivers, which have established a counter-power (Giddens, 1997) to the rule of the algorithm through their public visibility.

I argue that algorithmic management actually contributed to the emergence of these protests, despite the stated powerlessness of the workforce, due to the large-scale surveillance of all work activities. This is because the workers already contained within themselves the possibility of a countervailing power formation: power is 'typical of all action, so all dependencies yield certain resources for subjugated people, how they can influence the activities of rulers' (Giddens, 1997: 67). Furthermore, technological platforms facilitate joining with others and acting in concert with them (Arendt, 2017). 'Actively appearing', even through virtual communication, generates a 'public co-world' and establishes a sphere of human freedom through joint action (Arendt, 2018: 62). Drawing on Arendt (2018), I argue that the communicative exchange about everyday problems and personal concerns of the workers revealed commonalities to them, on which they based their agency. This is because action in such 'spaces of appearance'1 always encounters beings endowed with agency and never merely triggers reactions, but also inspires independent action, which then, in turn, affects other agents (215).

During the COVID-19 pandemic, frictions in labour relations concerning precarious working conditions have further intensified. New problems, such as the lack of protective equipment for the workforce and the resulting risk of infection and spread of the virus during work, have made the working infrastructure even more precarious. In this existential situation, the institutionalised organisation of workers has built an active opposition to the employer, demanding a guarantee of the safety measures, which should come from the platform side.

\section{Methods}

Based on a qualitative case study of gig workers working for Foodora/Lieferando, I examined on the one hand how algorithmic infrastructure manages its workforce, and on the other hand how the workers deal with this. The study drew on several different data sources, including ten semi-structured interviews (Lamnek \& Krell, 2010) and qualitative document analyses (Wolff, 2009) carried out between 2014 and 2021. These included websites, media reports, annual reports and a chat forum $(\mathrm{N}=103)$. The semi-structured expert interviews were conducted with 16 persons and lasted between 30 and 200 minutes. Of the ten interviews I conducted two interviews with four cyclists, so-called 'riders' with different hierarchical functions (2018) and one with a group of three riders (2020), all in the same hierarchical position. The data collection took place between November 2017 and October 2020 in three different German cities.

Access to the field proved to be a challenge at the beginning. I was able to get my first interview through a contact person. The person interviewed, in turn, provided me with further contacts. This snowball system worked well for two out of three cities. In the third

1 This term is a key in Arendt's theory, referring to, 'a creation of action ... and its existence is secured whenever actors gather together for the purpose of discussing and deliberation about matters of public concern, ... It is always a potential space that finds its actualization in the actions and speeches of individuals who have come together to undertake some common projects' (https://plato.stanford.edu/entries/ arendt/\#ActPowSpaApp). 
city, I obtained access by informal talks with waiting workers in a public place. The selection of research units was carried out step by step to generate the widest possible range of topics. Three of the 16 people were interviewed several times during the course of the research because they held, and in some cases still hold, key positions in the articulation of workers' voice and the collective bargaining process. To guarantee anonymity, the interviewees were assigned a code throughout the text. The code works in the form of their hierarchical position (there are only three different hierarchical levels: rider, rider captain (team leader), and senior rider captain (department manager). This also applies to the works council representatives with whom I spoke. All but two of the interviewees were male, which reflects but does not fully describe, the male-dominated workforce. All of those interviewed were cyclists, and eight people had a background as migrants. The interviewees came from different hierarchical areas (eight riders, three rider captains and five senior rider captains). The average age of all interviewed persons was 23.4 years, with a range of the age cohort between 20 and 37 years.

I conducted all interviews by myself and translated the quotes into English. While seven out of ten interviews were face-to-face and on location, three interviews were conducted by telephone or video conferencing in 2020. I wrote all interviews down using protocols with narrative passages, which provide information about the context and the conditions of origin.

At the beginning of the analysis, the different topics that emerged from the first interview(s) and their context were localised and then translated into concepts as headlines (Glaser \& Strauss, 1998). The interwoven data collection and data analysis thus relied on the first step, using an inductive approach through open coding. The sequential procedure followed the grouping of the NVivo codes into categories and generated common themes. This open coding category system was also continuously modified in the ongoing coding process. The inductively developed category system was tested and differentiated through the deductive themes identified in the literature and the document analysis. After the analysis I developed a case portrait of the organisation, which contains information on the analysis of documentary sources (websites, media reporting, annual reports, social media sources). Nevertheless, the sample was numerically limited and not fully representative of the whole workforce.

\section{Findings}

Foodora/Lieferando claims that it is not part of the gig economy (Knieps, 2021) because it employs its courier drivers in Germany on contracts with fixed working time models. Indeed, the workforce is subject to social insurance contributions. Nevertheless, the working conditions of the individual riders point towards a gig economy model. The governance by algorithmic management reveals the shifting of entrepreneurial risks which, in the extreme situation of the COVID-19 pandemic, is revealed very clearly as if through a magnifying glass.

\section{The company}

Foodora started under the name 'Volo' in Munich as a bicycle delivery service for restaurants in the premium sector in 2014. The investment company Rocket Internet bought Volo, renaming it 'Foodora' in spring 2015 (Wirminghaus, 2015), and then 
resold the start-up to Delivery Hero (in which Rocket Internet held a 30\% stake) for 13.2 million euros in the autumn of 2015 (Kyriasoglou, 2017). Delivery Hero sold its German business (Lieferheld, Pizza.de, Foodora Germany) to its Dutch competitor Takeaway for almost 1 billion euros in the winter of 2018. Through this sale, Delivery Hero became a shareholder of Takeaway. After the acquisition, Foodora became Lieferando in 2019, bringing the number of restaurants in Germany connected to the platform to approximately 18,000 and established a (temporary) quasi-monopoly as market leader in the field of food delivery. I have used the term Foodora/Lieferando to refer to this company in this paper, reflecting the fact that the name changed during the course of my research. The Dutch group Takeaway acquired the British competitor Just Eat and renamed itself 'Just Eat Takeaway' in 2020.

Foodora/Lieferando recorded 'a significant influx of new restaurants' in March 2020 (DPA, 2020). In total, more than 25,000 new restaurants were estimated to have access to the platform in that year (Petter, 2020). While internal company representatives spoke of the loss of thousands of restaurants, collapsed orders and sales figures (ibid.), sales doubled from 80 million euros in 2019 to 161 million euros in 2020 (Knieps, 2021). Internally the management discussed short-time work and early holidays. Nevertheless, globally, the food-delivery service has been growing during the coronavirus pandemic period (Chow, 2020). Foodora/Lieferando has benefited fully from the pandemic situation since April 2020, when its order numbers rose by $34 \%$ compared to the same period of the previous year (Ciesilski et al., 2020). Furthermore, the number of active users grew by $28 \%$ to 12 million in 2020 . These customers ordered food worth 2.5 billion euros, which is an increase of $75 \%$ compared to 2019 (Knieps, 2021). According to Lieferando only $7 \%$ of the deliveries ordered over the platform were delivered by their riders. So, the restaurants still deliver $93 \%$ of the orders using their own personnel. Nevertheless, the service is still not profitable in Germany (Spinnler, 2021).

\section{Foodora/Lieferando as an employer}

Foodora/Lieferando depends on algorithmically mediated platform structures to coordinate its business, and it is this technical infrastructure that is crucial for the success of the company:

The algorithms behind the platforms ensure that the order and delivery quality is constantly improving. In this way, we provide restaurants with technology for order entry, delivery, or tracking. At the same time, we also help customers choose the right restaurant based on their food preferences and expected delivery times [. . . That's why our technology is so important. For us, having our fleet is only worthwhile if the riders have short distances and short waiting times. We must be able to anticipate demand and react quickly. (CEO Östberg quoted in Schröder, 2016)

The central logistic algorithm is the key feature of the company, but this is only 'worthwhile' if it can draw on enough data to forecast the participants' behaviour. This is one reason, suggested by an interviewee, why Foodora operated with employed couriers in Germany, although it cannot explain why it operates with individual contractors in all other countries (Tassinari \& Maccarrone, 2020). Lieferando copied 
this specificity, having analysed the problems of its competitors and deciding to take over some features on the grounds that they could be a strategic benefit for its market leadership. This included having its own fleet of employed riders:

Lieferando has taken over a market and relies on its delivery fleet. This own delivery fleet adds a tactical, strategic component, which is what the company is all about. (Senior rider captain 4, 2020)

For Foodora/Lieferando the decision to own its fleet was a tactical one, based on the fact that the British provider Deliveroo, its main competitor, had experienced problems with hiring pseudo-independent riders. Furthermore, an in-company fleet ensured the visibility of the brand as well as discouraging restaurants from setting up their own delivery services. While the riders have to bring in their working equipment in all companies, Just Eat Takeaway signalled that it could provide e-bikes to its riders if necessary and would pay 10.50 euros per hour from the start (Foodora paid the minimum wage). However, the riders have to provide their own smartphone, as well as paying for the requisite data volume. One problem that Foodora had experienced, according to Lieferando's analysis, was that it had not been able to prevent all interest representation structures.

And now we are starting all over again at Lieferando. But with a management that is fighting us very much. (Senior rider captain 5, 2020)

Foodora Germany continued to operate as an independent platform from the sale of Just Eat Takeaway until the beginning of 2019. Meanwhile, Lieferando tried to convince the Foodora couriers to transform their old contracts into new ones with Lieferando. This, so an interviewee told us, was to prevent the workers of Foodora and Lieferando from having a works council to stand up for their interests. Ostensibly Lieferando claimed that the changed contracts would lead to better pay and facilitate a smoother workflow. But it also wanted to get rid of all co-determination rights as part of this changeover.

While Foodora used a proprietary algorithm that was constantly under development in Germany (and continues to do so in other countries), Lieferando uses an open-source variant from google firebase. So, although the back end of the two algorithms differs, there is only a small difference for couriers, restaurants and clients in the front end. The algorithm behind the platform provides the infrastructure for restaurants, which present their offers there. Customers use the platform to demand the food they want. If the matching is successful, both the restaurant (which receives $30 \%$ of the offer price) and the customer (in the form of a delivery fee of 2.50 euros) pay a commission to Lieferando (Schreyer, 2019).

The ongoing COVID-19 pandemic and the (partial) lockdown during the second wave motivated Lieferando to offer discounts to restaurants in Germany in November 2020 . For the use of the platform, restaurants had to pay $9.75 \%$ instead of a $13 \%$ commission. For the delivery by Lieferando couriers, the platform demanded $22.25 \%$ instead of 30\% (Ciesilski et al., 2020).

Figure 1 shows schematically how, after a successful matching of supply and demand on the platform, the rider receives the order. It focuses on the address of the restaurant. At the restaurant, the rider picks up the food and confirms it in the app. 
Then the customers' address is released. A confirmation of the rider in the app is necessary when the food is delivered. Afterwards, the rider gets a new order or drives to a defined starting point to wait for orders.

The algorithmic management behind the platform has thus rationalised and designed all activities for the participants in modular units. Due to the 'high usability of the app and the simple user interface' (Rider 4, 2018), the algorithmic management facilitates the whole workflow of the riders, while assisting them with information. Working under an algorithm means, 'you only get the most necessary information and work step by step' (Rider 3, 2018). But this information asymmetry is not always efficient for the workers because they cannot gain an overview of the entire delivery process and must therefore rely on the technical instructions. This means that the workers cannot bring their own practical knowledge, for instance, about the environmental circumstances, into the working process.

The intermediary position of the algorithmic management encompasses tasks such as distributing the orders, allocating the order volume to the available workers of a shift, calculating the routes, activating the addresses and storing the performance data of the works as well as the consumption choices of the customers. The technical infrastructure of the platform registers and stores all the workers' activities, such as their clicks, their GPS signals and their speed. In the words of one of our interviewees:

with the combination of location, route, and time you can evaluate and create entire profiles of your employees. And you can also look at your operational business, where are the weaknesses, because you can triangulate the data from several riders. (Senior rider captain 4, 2020)

To sum up, the algorithmic management system makes it possible to 'exert control over their workforces' (Shapiro, 2018) using quantitative measures. To the workforce,

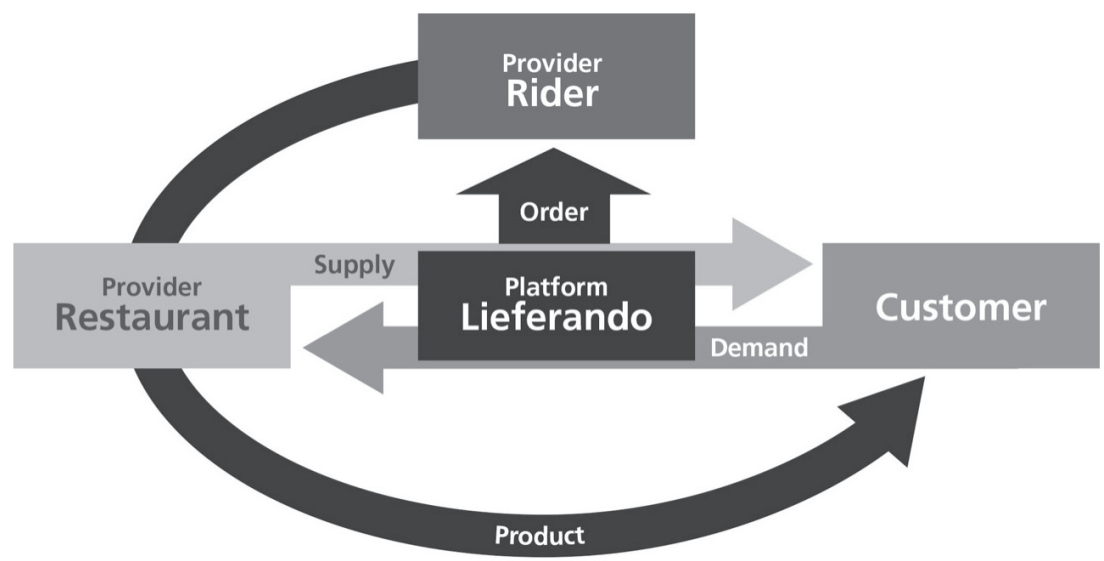

Figure 1: Mode of operation.

Source: Author's elaboration. 
the algorithm behind the app remains a black box. These 'new' normal 'data-driven techniques of remote worker control, such as behavioural nudges and scheduling prompts based on volatile real-time and predictive analytics' (van Doorn, 2017), show that the algorithmic management system is 'restricting' and 'recommending' the whole working process (Kellogg et al., 2020). Worker evaluation through recording and rating leads to disciplinary mechanisms like 'rewarding' through bonus systems or gamification and 'replacing' in the sense of bringing forward or delaying access to the shift booking. In the next section, I investigate what this kind of algorithmic governance means for the workforce.

\section{The on-demand workforce}

Due to the high fluctuation in the size of the workforce, the general volatility of employment relationships, the fragmented nature of the work and the absence of a centralised workspace as a regular meeting place, social relations can hardly develop during the labour process. It is therefore not surprising that neither the algorithmic work coordination nor the surveillance and control associated with it was seen as the primary problem from the point of view of the interviewees for a long time. Rather, riders complained about poor working conditions and the avoidance of traditional employment duties by the platform. A big issue was the lack of work equipment. Besides their bicycles, which they brought in, more or less, voluntarily, and the wear and tear on these vehicles, they asked why they had to use their own smartphones. The need to purchase data volume, which is required for the app to be workable, was another serious issue because, and this was the next big problem, their wages were too low. Another important issue for all interviewed riders over the years for both Foodora and Lieferando was unpaid working time:

So, the employer only wants to pay for what he thinks is 'real' work that you do here. And that is always just the delivery. The delivery drives, that's it. We have problems here again and again with holidays, sick days, and other benefits that one should get as an employee. (Rider 2, 2018)

The algorithmic management system defines the work process closely and limits it to modular units because the algorithm only observes these quantitative, standardised measures. This means that the human resource department is responsible for any qualitative concerns. However, there is no permanently staffed office at the locations. Facilities are only open during certain office hours. Therefore, almost all communication between the platform and the workers happens through the app. One interviewee said that this would help to ensure that communication is kept manageable:

Communication is being limited to a means of communication that is contemporary, they [human resources department] said. This is not face-to-face, but only via digital. (Rider Captain 1, 2018)

Lieferando implemented a ticket system, where the riders have to sort out, beforehand, which category they wish to address, for example: whether they want to raise an issue about a sickness report, accident, holiday or other issue. If an answer comes at all, the general experience is that no one in the company takes responsibility. As one interviewee told us: 
The riders are also treated like customers. Writing tickets to the human resource department. And they are kept out of the company. You only want to control them remotely; they are supposed to deliver the cell phone data, and the customers do that, too. (Senior rider captain 5, 2020)

Only $80 \%$ of the requests made using the ticket system receive an answer. The employees of the human resources department, who are responsible for the response rate, practise a diffusion of responsibility. This is why some works councils are taking legal action to eliminate the ticket system. Further problems relate to shift evaluation and incomplete payments. A member of the works council said that this often happens, in particular to people with a migrant background.

It is simply that entrepreneurial risk passed down to the employee [. . .] Also, it is a negative human resources policy. So, you always go into discussion under suspicion. For example, when someone discusses his or her shift evaluation. Then they look, 'ohh is that a point at all. Or has he not cheated us'. (Rider captain 3, 2018)

The centralised and depersonalised communication between cyclists and the human resources department makes it difficult for individual riders to receive full payment. There is a wide variance related to different facets of unpaid work. For instance, not all riders have full-time contracts. So, it becomes problematic for them to pick up new equipment, such as back bags or branded clothing, because of the limited office hours. Also, bike maintenance after a shift or an accident within a shift is partially unpaid work:

If someone has had an accident, this is documented to the exact minute, but the time the rider writes an accident report is then no longer working time. (Rider 5, 2018)

After many fights, Foodora/Lieferando pays a monthly wear and tear fee. But such things as writing an accident report or booking a shift are under continuous dispute between the workers and the employer because this unpaid working time is not registered by the algorithmic management system, which does not monitor this 'qualitative data'.

Taking all these practices together, a clear picture emerges in which the platform as an employer shifts its entrepreneurial risk to the workforce, a shift that is accompanied by a precarisation of the position of the individual workers (Leonardi et al., 2019). Overall, the problematic situations that were reported show on the one hand how precarious the labour infrastructure is and on the other hand how the conflict of interests between workers and employers is becoming evident, and resistance to these practices had been emerging. I therefore argue that while the algorithmic management system collects data and produces social knowledge about their workforce, which provides it with power over the workers, it had no capability of hindering protests, but, on the contrary, facilitates organising because of its rigid control mechanism and the lack of measures that would enable it to communicate directly to address issues such as those relating to unpaid work, or work security services. 


\section{Workers' voice}

Despite the absence of a central workplace, the high fluctuation and general volatility of the employment structures, as well as the difficulty of forming collective identities and voice, international, transnational, national and regionally coordinated protests of bikemessenger of Foodora, Deliveroo and other platform-based companies have been spreading since 2016. These began in several cities in Great Britain, and attracted considerable public attention (Tassinari \& Maccarrone, 2020). Furthermore, in Italy protests from courier drivers for Foodora arose in Turin (Marrone \& Finotto, 2019). At the same time, Deliveroo and Foodora workers protested in Berlin (Degner \& Kocher, 2018).

All these protests showed similarities in their demands: an improvement in working conditions and remunerations structures. Also, all workers criticised the fact that they had to bring in their own work equipment themselves, the lack of direct contact with people to answer any questions and the insecurity of the employment structures. In the autumn of 2016, representatives from these campaigns came together at a conference in Bilbao. At this meeting, eight international grassroots trade unions founded the campaign \#deliverunion to coordinate international cooperation and to inform delivery workers about their rights.

The reason why protests arose, according to my thesis, is because bike messengers found a way to express and share their daily concerns. The virtual communicative exchange had shown that they were all affected by similar problems:

There was a WhatsApp group in which riders came along. There was a lot of discussion about problems. There was a lot of displeasure to be heard. We built the first community with people who wanted to improve working conditions and who asked critical questions. More questions arose that needed to be answered. Classic works council tasks were brought up there. (Rider captain 2, 2018)

This initial self-organisation formed a community based on personal dismay that grew by a snowball system. They articulated common difficulties, formulated demands and built up solidarity and a shared identity. Because

power arises when people come together and act together; its legitimacy is not only based on the goals and purposes that a group sets for itself in each case; it stems from the origin of power that coincides with the formation of the group. (Arendt, 2017: 53)

This was illustrated in the words of one of our interviewees.

For me, the decisive reason was that you don't get anywhere with your criticism here. You realise that you're being used and exploited, but you don't get anything in return. And other drivers thought this, too. Somehow you get more and more obligations and also penalties, but in return, something is missing. (Senior rider captain 4, 2020)

Since 2017, some cycle messengers had been organising get-togethers with (basic) trade unions in Germany. Under the umbrella of the \#deliverunion campaign, courier drivers and the unions Ver.di (United Service Union), FAU (Free Workers Union) and NGG (Union for food, catering and luxury goods) worked out a 
catalogue of demands and underlined it with public actions in front of the company headquarters (Degner \& Kocher, 2018). The claims were about the work equipment, which should be provided, an improvement of work safety, and the covering of bicycle repairs. Also, they demanded more transparency in the allocation of shifts and the billing process of worked hours. As a long-term goal, the drivers were striving for a collective agreement.

While Deliveroo had not reacted to any actions and completely refused negotiations, Foodora, in Germany at least, gave the impression of acting in a spirit of 'social partnership' by participating - more or less symbolically - in sectoral negotiations with trade unions. The first round of negotiations between Free Workers Union Berlin and Foodora - shortly before the initial public offering (IPO) of its parent company Delivery Hero - signalled its willingness to implement some of the demands partially. But after the second round, the Free Workers Union (AU) in Berlin declared the negotiations as failed because there were no concrete improvements to be expected from the company side (FAU, 2017).

Foodora was also hostile to collective interest representation on the shop floor in Germany, too. The company prevented several attempts to set up a works council in 2017. Some of the strategies used by the platform included failing to renew the fixed-term contracts of engaged workers to stop works councils from being set up. (Riders were given no notice of termination and realised that they had been dismissed only when denied access to the app) and scheduling election meetings on Sundays at a time when most of the couriers were working and on the streets.) By the end of 2018, only two works councils existed, out of 34 potential locations. Nevertheless, the Works Constitution Act 47 (1) requires that if a company has several works councils at different sites, it must set up a central works council. So, they established a general works council, which is responsible for dealing with matters that affect the entire company and cannot be dealt with by individual works councils within the sites. Six out of thirty-six sites had a works council by 2020 .

The transition of these co-determination structures to Lieferando was difficult. After its takeover of Foodora, Lieferando put pressure on Foodora workers in companies with works councils and forced almost all of them to leave, only to rehire them again in a Lieferando company without a works council. However, the members of the Foodora works councils went to court, which forbade this practice. Lieferando then abandoned this strategy of having two companies in a single city. Currently, since October 2020, all six works councils are again responsible for all the employees in their city.

Nevertheless, the platform is still trying to ignore the works council, and work with the same delaying tactics as described above. However, the COVID-19 pandemic has made the works council even more essential for the workforce because, against all statements to the contrary by Lieferando, couriers have been missing protective equipment, and the already precarious labour infrastructure has been worsened considerably by the pandemic event. By mid-March 2020, the riders had received neither the promised hygiene equipment (antibacterial hand disinfectant, masks, and gloves) nor any safety training (except in the form of various generic round-robin e-mails) (Wachter, 2020). One rider told us, 
If you want to protect yourself from COVID-19 at Lieferando, you have to take action yourself (Rider 2020, quoted in Petter, 2020)

While the atomisation of the workforce is a huge problem for individuals in times of pandemic because there are few possibilities to communicate directly with the human resource department, the general works council took over these matters for all employees of Lieferando in April 2020.

It was already April then I took matters into my own hands. I said, 'Where are the masks and what's going on'. And no one knew what to do. They always said, 'oh we're at it. It's going to take a little longer'. And I was like, 'what are the measures now?' And we [the general works council] decided that we had to go to press.

(Senior rider captain 5, 2020)

At this time, the restaurants were closed to eat-in customers and provided only takeaway food, so another problem, besides the protective equipment, was a lack of access to toilets and washing facilities. Although this was a repeated topic of discussion, the company had not taken care of it. The alliance 'Liefern am Limit' started a petition, demanding disinfectants, protective clothing and better working conditions for the riders at the end of April 2020. Despite this, the petition narrowly missed its target of 15,000 signatures. But Lieferando was triggered into taking some action because of the public involvement and provided masks for the drivers. But this, according to the interviewees, was only because the platform feared negative publicity:

There was the fear, what is it if one of our people has the virus now and then infects a customer or a restaurant employee. There you have a huge rat tail of infection chain. (Rider 7, 2020)

It seems very likely that, without the workers' protest (especially in virtual chat rooms) in conjunction with the institutionalised interest representation, which acted as the workers' voice, safety measures would still be an individual matter. However, the institutionalised form of co-determination made it possible to initiate the implementation of occupational safety measures by the platform. They also ensured that conflicts, in this time of existential danger, were not (too much) delayed, using the threat of going public or directly to court. Due to the constant organisation of the workers, their supra-regional networking and communication functioned as a counterweight to the employer and helped in times of pandemic to force action on the employer side.

\section{Conclusion}

This article has examined whether algorithmic management structures prevent or facilitate protests by an on-demand workforce with precarious working conditions and how this works (van Doorn, 2020; Duggan et al., 2020; Kirchner \& Schüßler, 2019).

In their self-description, Foodora/Lieferando argue that they are not part of the gig economy. But both companies aim at exploiting regulatory gaps through comprehensive algorithmic quantification, coordinating the workforce on a job-specific basis, and a high degree of control of all work processes. This system favours the 
shifting of entrepreneurial risks to the individual rider and reflects the platform's effort to evade employer obligations.

Despite these challenging starting conditions for organising employee interests, the technical infrastructure of the platform entails the potential for collective organisation due to the inherent imbalance of power whereby algorithmic management exercises a rigid system of control but can only respond within a standardised framework. The limited, centralised and depersonalised human communication creates dissatisfaction among workers (and works councils) because their concerns are not addressed, or, when they are, only with a delay. This delaying tactic is a general characteristic of the employer. It can therefore be argued that qualities inherent in the platform architecture actually accelerated the processes motivating workers to get together, because of its limited scope for communication. The workforce met virtually, exchanged ideas, and bundled their discontent in a self-organising movement, which publicly denounced the grievances against the company and demanded more rights and recognition.

The successful establishment of works councils on the shop floor level as well as the supra-regional and international associations in which they participated show that online technologies do not only advance control and power but also open up the possibility for workers to get in contact with like-minded people, to maintain communication and to form a counterweight to the employer. Establishing a countervailing power is laborious and small-scale but quite effective. As the example has shown, especially in the COVID19 pandemic, the precarious working conditions would have been even more precarious without such a countervailing power: without the publicity measures and protests, the platform would not have acted by itself (or at least not so quickly) and launched at least this minimum of protective measures for its workers.

(C) Jasmin Schreyer, 2021

\section{ACKNOWLEDGEMENTS}

The research on which this article is based was carried out within the project 'Digital Project Communities as Innovation Incubators', which was part of the research network 'Digitalisation, Co-determination, Good Work' of the Hans Böckler Foundation from 2017-2020; this research was funded by the Hans Böckler Foundation.

\section{REFERENCES}

Arendt, H. (2017). Macht und Gewalt, Deutsche Erstausgabe, 26 Auflage, München: Piper.

Arendt, H. (2018). Vita activa oder Vom tätigen Leben, München/Berlin/Zürich: Piper.

Chow, L.S. (2020). 'Foodservice waging war against Covid-19 crisis and the opportunity', Journal of Tourism, Hospitality \& Environment Management, 5 (19):41-49.

Ciesilski, R., S. Khamis, J. Lenz \& V. Schälter (2020) 'Mitarbeiter fühlen sich vom Lieferdienst Lieferando überwacht', tagesschau.de. Accessed 21 November 2020. https:// wwwtagesschaude/wirtschaft/lieferando-arbeitsbedingungen-101html

De Stefano, V. (2016). The rise of the "just-in-time workforce», on-demandwork, crowdwork and labour protection in the "gig-economy» No. 71, Geneva: International Labour Office.

Degner, A. \& E. Kocher (2018). 'Arbeitskämpfe in Der “Gig-Economy"? Die Protestbewegungen Der Foodora Und Deliveroo “Riders” Und Rechtsfragen Ihrer Kollektiven Selbstorganisation', Kritische Justiz, 51 (3):247-265.

Dijck, J., T. Poell \& M. de Waal (2018). The platform society, New York: Oxford University Press.

van Doorn, N. (2017). 'Platform labor: On the gendered \& racialized exploitation of low-income service work in the 'on-demand' economy', Information, Communication \& Society, 20 (6):898-914. 
van Doorn, N. (2020). 'At what price? labour politics \& calculative power struggles in on-demand \& food delivery', Work Organisation, Labour \& Globalisation, 14(1):136-149.

DPA (2020). 'Corona: Immer mehr Restaurants liefern über Lieferando aus'. Accessed 21 November 2020. https://wwwbusinessinsiderde/wirtschaft/handel/corona-immer-mehrrestaurants-liefern-ueber-lieferando-aus/

Duggan, J., U. Sherman, R. Carbery \& A. McDonnell (2020). 'Algorithmic management \& app-work in the gig economy: A research agenda for employment relations and HRM', Human Resource Management Journal, 30 (1):114-132.

FAU (2017). 'Who's hub? Our hub! - Deliverunion'. Accessed 25 September 2020. https:// deliverunionfauorg/2017/11/15/whos-hub-our-hub/.

Frenken, K. \& J. Schor (2017). 'Putting the sharing economy into perspective', Environmental Innovation \& Societal Transitions, 23:3-10.

Giddens, A. (1997). Die Konstitution der Gesellschaft: Grundzüge einer Theorie der Strukturierung, Frankfurt/Main: Campus-Verlag.

Glaser, B.G. \& A.L. Strauss (1998). Grounded theory: Strategien qualitativer Forschung, Bern: Huber.

Goods, C., A. Veen \& T. Barratt (2019). “'Is your gig any good?” Analysing job quality in the Australian platform-based food-delivery sector', Journal of Industrial Relations, 61 (4):502-527.

Healy, J., D. Nicholson \& A. Pekarek (2017) 'Should we take the gig economy seriously?' Labour \& Industry: A Journal of the Social \&Economic Relations of Work, 27 (3):232-248.

Healy, J., A. Pekarek, \& A. Vromen (2020). 'Sceptics or supporters? Consumers' views of work in the gig economy', New Technology, Work \&Employment, 35 (1):1-19.

Huws, U. (2014). Labor in the global digital economy: The cybertariat comes of age, New York: Monthly Review Press.

Huws, Ursula. 2016. 'Logged labour: A new paradigm of work organisation?' Work Organisation, Labour \& Globalisation, 10 (1):7-26.

Huws, U., N. Spencer, D. Syrdal \& K. Holts (2017). Work in the European gig economy research results from the UK, Sweden, Germany, Austria, The Netherlands, Switzerland and Italy, Brussels: Foundation for European Progressive Studies.

Joyce, S., D. Neumann, V. Trappmann, \& C. Umney (2020) A global struggle: Worker protest in the platform economy. ETUI research paper. Policy brief, February.

Kellogg, K.C., M.A. Valentine \& A. Christin (2020). 'Algorithms at work: The new contested terrain of control', Academy of Management Annals, 14 (1):366-410.

Kirchner, S. \& E. Schüßler (2019). 'The organization of digital marketplaces: Unmasking the role of internet platforms in the sharing economy', in Ahrne G. \& N. Brunsson (eds), Organization outside Organizations, Cambridge: Cambridge University Press:131-154.

Knieps, S. (2021). Lieferando-Deutschland-Chefin: 'Wir sind nicht bloß ein Wimpernschlag in einer Coronaphase'. Accessed 9 May 2021. https://wwwwiwode/unternehmen/dienstleister/ lieferando-deutschland-chefin-wir-sind-nicht-bloss-ein-wimpernschlag-in-einercoronaphase/27036696html

Kuhn, K.M. \& T. Galloway (2019). 'Expanding perspectives on gig work \& gig workers', Journal of Managerial Psychology, 34 (2019):186-191.

Kyriasoglou, C. (2017) 'So steht es um Foodora', Gründerszene Magazin, Accessed 24 September 2020. https://wwwgruenderszenede/food/foodora-geschaeftszahlen-2016-delivery-hero-ipo

Lamnek, S. \& C. Krell (2010). Qualitative Sozialforschung: Lehrbuch, Weinheim Basel: Beltz.

Lehdonvirta, V. (2018). 'Flexibility in the gig economy: Managing time on three online piecework platforms, New Technology, Work \& Employment, 33 (1):13-29.

Leonardi, D., A. Murgia, M. Briziarelli \& E. Armano (2019). 'The ambivalence of logistical connectivity: A co-research with Foodora Riders', Work Organisation, Labour \& Globalisation, 13 (1):155-171.

Levermann, T. (2018). 'Wie Algorithmen Eine Kultur Der Digitalität Konstituieren: Über Die Kulturelle Wirkmacht Automatisierter Handlungsanweisungen in Der Infosphäre', Journal Für Korporative Kommunikation, 2:31-42. 
Marrone, M. \& V. Finotto (2019). 'Challenging goliath informal unionism \& digital platforms in the food delivery sector the case of riders union Bologna', The Open Journal of Sociopolitical Studies, 12 (3):691-716.

Petter, J. (2020). Corona-Krise bei Lieferando: 'Wir gehen in den Park, wenn wir aufs Klo müssen', Spiegel. Accessed 21 November 2020, https://wwwspiegelde/panorama/coronavirusbei-lieferando-wir-gehen-in-den-park-wenn-wir-aufs-klo-muessen-a-ff05f574-0ffa-4768922e-3b0fdbf27a12

Rosenblat, A. \& L. Stark (2016). 'Algorithmic labor and information asymmetries: A case study of Uber's drivers, International Journal of Communication, (10):3758-3784.

Schreyer, J. (2019). 'Das Phänomen Sharing Economy am Beispiel des Foodsektors, HBS Working Paper Forschungsförderung 145', Düsseldorf: Hans-Böckler-Stiftung.

Schreyer, J. (2020). 'Sharing $\neq$ Sharing economy. Ausprägungen Der Digitalen Sharing Economy Im Lebensmittelsektor', Discussion Paper 2020-03, Stuttgart.

Schreyer, J. (2019). 'Das Phänomen Sharing Economy am Beispiel des Foodsektors', Working Paper 145, Düsseldorf: Hans-Böckler-Stiftung.

Schreyer, J. \& J. Schrape (2018). 'Algorithmische Arbeitskoordination in Der Plattformbasierten Gig Economy: Das Beispiel Foodora', Arbeits Und Industriesoziologische Studien, 11 (2):262-278.

Schröder, M. (2016). 'Der Markt Hat Nur Platz Für Einen Oder Zwei Anbieter' | Delivery Hero. Accessed 24 September 2020. https://wwwdeliveryherocom/der-markt-hat-nur-platz-fureinen-oder-zwei-anbieter/

Shapiro, A. (2018). 'Between autonomy \& control: Strategies of arbitrage in the "on-Demand" economy', New Media \& Society, 20 (8):2954-2971.

Slee, T. (2016). Deins ist meins: die unbequemen Wahrheiten der Sharing Economy, München: Verlag Antje Kunstmann.

Spinnler, T. (2021). 'Lokale Konkurrenz trotzt Lieferando', tagesschau.de. Accessed 21 May 2021. https://www.tagesschau.de/wirtschaft/unternehmen/lieferando-wolt-lokale-lieferdienstekonkurrenz-101.html

Srnicek, N. (2017). Platform capitalism, Cambridge: Polity.

Tassinari, A. \&V. Maccarrone (2020). 'Riders on the storm: Workplace Solidarity among gig economy couriers in Italy \& the UK', Work, Employment \&Society, 34 (1):35-54.

Vallas, S. \& J.B. Schor (2020). 'What do platforms do? Understanding the gig economy', Annual Review of Sociology, 46 (1):273-294.

Wachter, D. (2020). 'Streit bei Lieferando: Schützt das Unternehmen seine Fahrer genug vor Coronaviren?' Stern.de. Accessed 21 November 2020. https://wwwsternde/genuss/essen/ lieferando--betriebsrat-beschwert-sich---fahrer-sollen-keine-hygieneausruestung-erhaltenhaben-9183772html

Wewer, G. (2016). 'Privates Teilen Als Geschäftsmodell? Politische, Wirtschaftliche Und Soziale Probleme Der Sharing Economy', Leviathan, 44 (1):155-179.

Wirminghaus, N. (2015). 'Rocket reicht Foodora an Delivery Hero weiter', Gründerszene Magazin. Accessed 24 September 2020. https://wwwgruenderszenede/allgemein/foodoradelivery-hero

Wolff, S. (2009). Dokumenten- Und Aktenanalyse Flick, U. E. Kardorff \& I. Steinke (eds), Qualitative Forschung Ein Handbuch, Hamburg: Rowohlt Taschenbuch Verlag:502-514.

Wood, A.J., M. Graham, V. Lehdonvirta \& I. Hjorth (2019). 'Good gig, bad gig: Autonomy and algorithmic control in the global gig economy', Work, Employment \& Society, 33 (1):56-75.

Zuboff, S. (2018). Das Zeitalter des Überwachungskapitalismus, Frankfurt/New York: Campus Verlag. 